\title{
Radiotherapy and erlotinib combined: review of the preclinical and clinical evidence
}

\section{Vivek K. Mehta*}

Department of Radiation Oncology, Swedish Cancer Institute, Seattle, WA, USA

\section{Edited by:}

Brian Timothy Collins, Georgetown Hospital, USA

\section{Reviewed by:}

Christopher Schultz, Medical College of Wisconsin, USA

Michael Wayne Epperly, University of

Pittsburgh Cancer Institute, USA

\section{*Correspondence:}

Vivek K. Mehta, Department of Radiation Oncology, Swedish Cancer Institute, 1221 Madison Street, First Floor, Seattle, WA 98104, USA.

e-mail: vivek.mehta@swedish.org
Epidermal growth factor receptor (EGFR) is often overexpressed in tumors and has been associated with poor prognosis in some cancer types. The introduction of inhibitors of EGFR, such as erlotinib, represents an important recent advance in the targeted treatment of cancer. Several studies have evaluated inhibitors of EGFR in combination with radiotherapy, and a strong biologic rationale exists for the use of this combination in certain cancer types, including head and neck squamous cell carcinoma, non-small cell lung cancer, glioblastoma, esophageal cancer, and pancreatic cancer. Preclinical and clinical studies are underway to evaluate the combination of erlotinib with radiotherapy. To date, the results suggest that this approach is at least feasible and may result in modest improvement in outcomes compared with either modality alone.

Keywords: radiotherapy, erlotinib, preclinical, clinical, epidermal growth factor receptor, radiation, EGFR

\section{INTRODUCTION}

Erlotinib is a small molecule inhibitor that reversibly targets the tyrosine kinase activity of the epidermal growth factor receptor (EGFR). EGFR is overexpressed and/or mutated in many cancer types, and its activation triggers pathways involved in cell growth and proliferation. Overexpression of EGFR in tumors often correlates with poor prognosis because of its involvement in tumor progression, angiogenesis, migration, and metastasis (Yarden, 2001). Some tumor types, such as head and neck squamous cell carcinoma (HNSCC), typically exhibit high levels of EGFR expression (Mendelsohn, 2001). At least a third of tumors exhibit EGFR dysregulation or overexpression, although the expression of EGFR does not always correlate with response to therapeutic EGFR inhibitors (Mendelsohn, 2001; Harari, 2004). In the United States, erlotinib is approved as monotherapy for previously treated locally advanced or metastatic non-small cell lung cancer (NSCLC) and in combination with gemcitabine for the first-line treatment of metastatic pancreatic cancer. Many clinicians are incorporating the use of erlotinib into treatment for other indications as well, particularly in the metastatic setting.

A pivotal trial in establishing a potential role for combining EGFR inhibition with radiotherapy (RT) was a randomized phase III trial that compared the use of cetuximab and RT with RTalone in locoregionally advanced HNSCC (Bonner et al., 2006). This study demonstrated a significant improvement in overall survival (OS) and local control in the experimental arm. A recent update of this study demonstrated that the improvements were durable with extended follow-up (Bonner et al., 2010). The 5year OS for 211 patients assigned to the combination arm was $45.6 \%$ compared with $36.4 \%$ for the 213 patients receiving RT monotherapy. Median OS for patients in the combination arm was 49.0 months compared with 29.3 months for patients assigned to RT-alone (hazard ratio $=0.73 ; 95 \%$ confidence interval, 0.56 $0.95 ; P=0.018)$. Moreover, with the exception of acneiform rash and infusion reactions, grade $\geq 3$ adverse events associated with the combination of cetuximab and RT did not appear to be worse than those associated with RT-alone (Bonner et al., 2006).

Erlotinib has been evaluated in combination with RT in a number of cancer types, and several studies are ongoing. This report describes the biologic rationale for combining erlotinib with RT, as well as the preclinical and clinical evidence that supports the use of this combination in various tumor types, including HNSCC, NSCLC, glioblastoma (GBM), esophageal cancer, and pancreatic cancer.

\section{RATIONALE FOR COMBINING ERLOTINIB WITH RT}

A strong rationale may exist for combining erlotinib with RT. Erlotinib helps disrupt cell growth pathways (Figure 1) and enhances the sensitivity of cells to the effects of RT (Chinnaiyan et al., 2005; Nyati et al., 2006; Baumann et al., 2007; Tortora et al., 2007; Marshall, 2011). It is also possible that RT enhances the effectiveness of erlotinib by cytoreducing the tumor and creating a hypoxic environment (Tortora et al., 2007). In addition, the rationale that supports combining a systemic agent and local therapy for maximal effect is applicable to this combination. Finally, toxicities associated with erlotinib and with RT are generally, although not completely, non-overlapping, which enables their concomitant use.

The optimal timing of the administration of RT and erlotinib has yet to be determined. Various trials have been designed to evaluate erlotinib given before, concurrently, and/or following the RT component of treatment. The potential benefit of using systemic chemotherapy or targeted agents, such as bevacizumab, in combination with erlotinib and RT also needs to be established.

\section{PRECLINICAL DATA WITH ERLOTINIB AND RT}

Several lines of preclinical evidence support the combination of erlotinib and RT in various cell types (Chinnaiyan et al., 2005). Erlotinib enhances the radiation response at several levels, including cell cycle arrest, apoptosis induction, accelerated 


\section{TUMOR CELL}

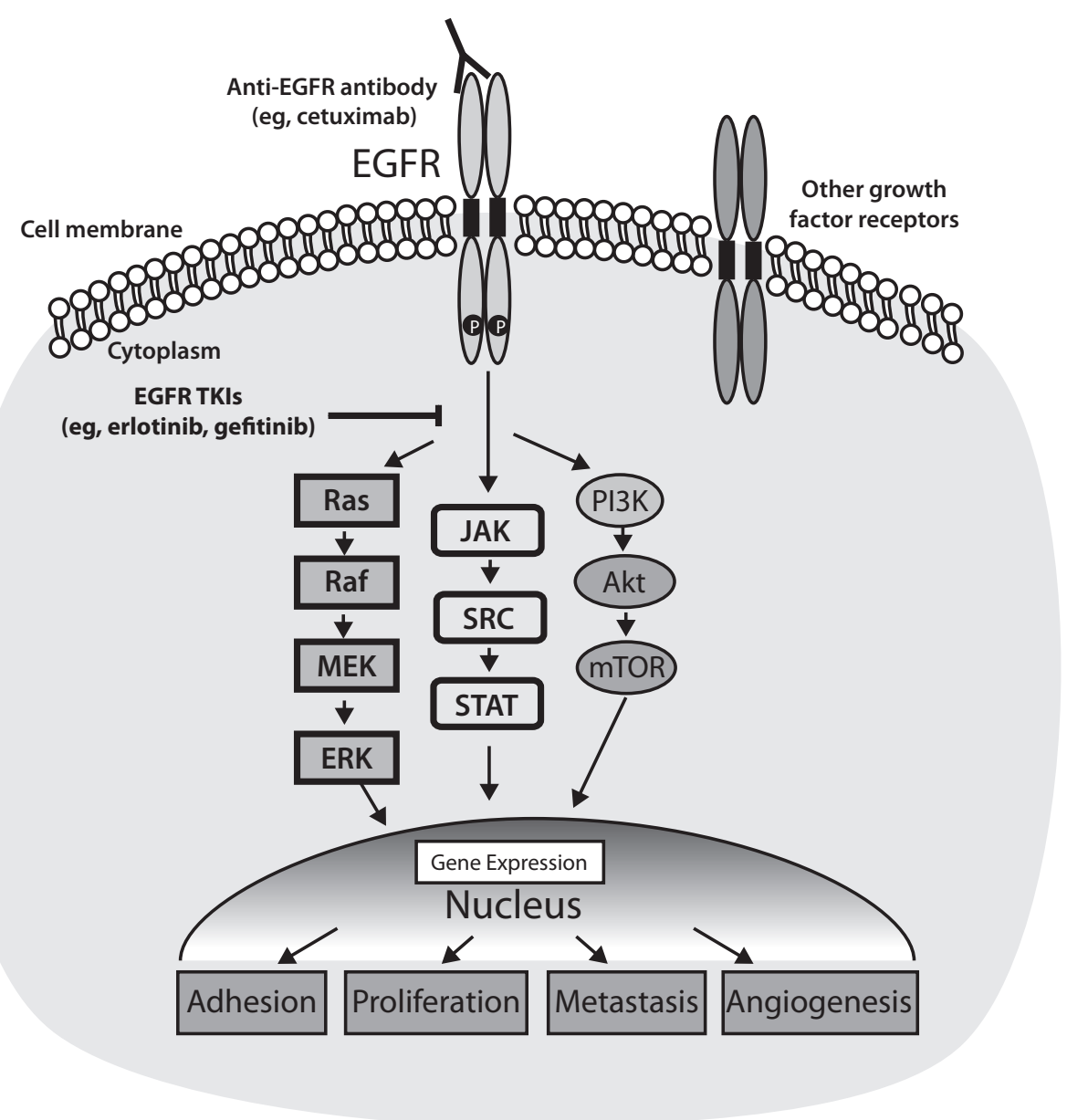

FIGURE 1 | Epidermal growth factor receptor (EGFR) activation of signal transduction pathways and points of inhibition by targeted therapies.

The activation of EGFR on tumor cells leads to phosphorylation of tyrosine residues in the kinase domain of the receptor and subsequent activation of the Ras/Raf/MEK/ERK, JAK-STAT, or PI3K/AKt/mTOR pathways. In turn, these pathways result in the activation of genes related to angiogenesis, cell proliferation, metastasis, and adhesion. Akt, v-akt murine thymoma viral oncogene homolog 1; EGFR, epidermal growth factor receptor; ERK, extracellular regulated kinase; JAK, Janus kinase; MEK, MAP kinase-ERK kinase; mTOR, mammalian target of rapamycin; PI3K, phosphatidylinosito 3-kinase; Ras, rat sarcoma viral oncogene homolog; Raf, v-raf-1 murine leukemia viral oncogene homolog 1; SRC, Rous sarcoma oncogene; STAT, signal transducer, and activator of transcription; TKIs, tyrosine kinase inhibitors. Adapted from Box 2 in Nyati et al. (2006) and Figure 2 in Marshall (2011). cellular repopulation, and DNA damage repair. Chinnaiyan et al. (2005) reported that erlotinib modulated the radiation response by influencing cell cycle kinetics and apoptosis. Erlotinib appeared to modify the effect of RT on EGFR autophosphorylation and Rad51 expression. In addition, erlotinib in combination with RT reduced the number of cells in S phase while increasing the level of apoptosis and promoting an increase in sensitivity to RT. In tumor xenografts, erlotinib combined with RT dramatically inhibited tumor growth (Figure 2), and microarray analysis indicated that the addition of erlotinib influenced the expression of radiation response genes from several functional classes, including cell cycle arrest and DNA damage repair (Chinnaiyan et al., 2005).

In a second preclinical study involving three human cancer cell lines with low, moderate, and very high EGFR expression, the extent of erlotinib-induced radiosensitization was found to be proportional to the expression and autophosphorylation of EGFR (Kim et al., 2005a). The cell line A431, which expresses very high levels of EGFR, demonstrated the highest degree of radioresistance, and treatment with erlotinib increased the extent of G1 arrest and augmented apoptosis in these cells.

Erlotinib and higher-dose RT have been shown to achieve an additive antitumor effect in a xenograft model of GBM (Sarkaria et al., 2006). In this preclinical study, an orthotopic GBM xenograft exhibiting EGFR amplification was transplanted into athymic mice; mice with established intracranial tumors were subsequently randomized to sham (control), RT, erlotinib, or erlotinib and RT. The combination of erlotinib and intensified RT (20 Gy/5 days), but not lower-dose radiation ( $12 \mathrm{~Gy} / 12$ days), produced a survival 


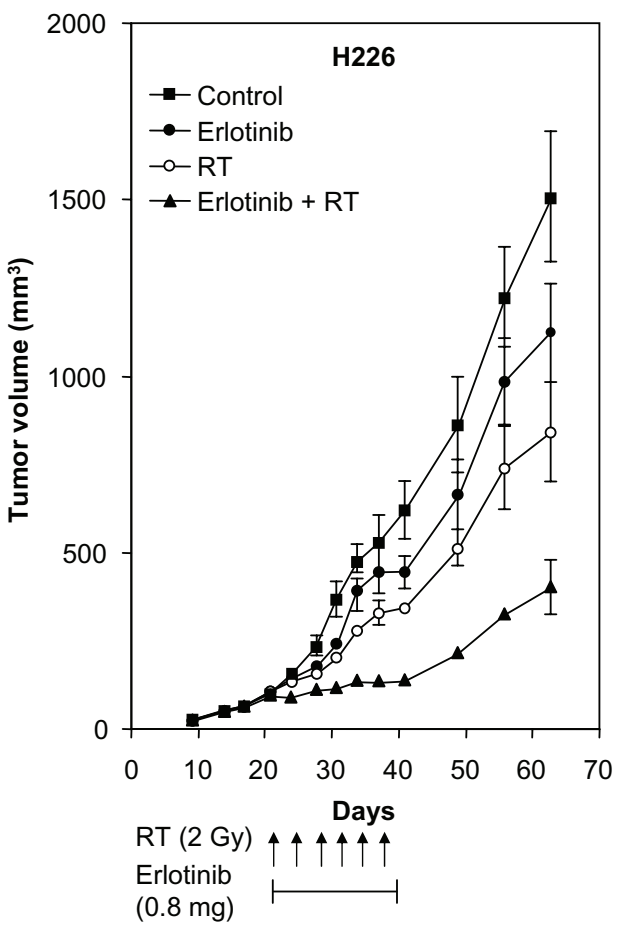

FIGURE 2 | In vivo activity of erlotinib with or without radiotherapy (RT) in tumor xenografts. $\mathrm{H} 226\left(10^{6}\right)$ or UM-SCC6 $\left(10^{6}\right)$ cells were injected subcutaneously into the flanks of athymic mice as described. Mice were treated with erlotinib $(0.8 \mathrm{mg}$ daily via

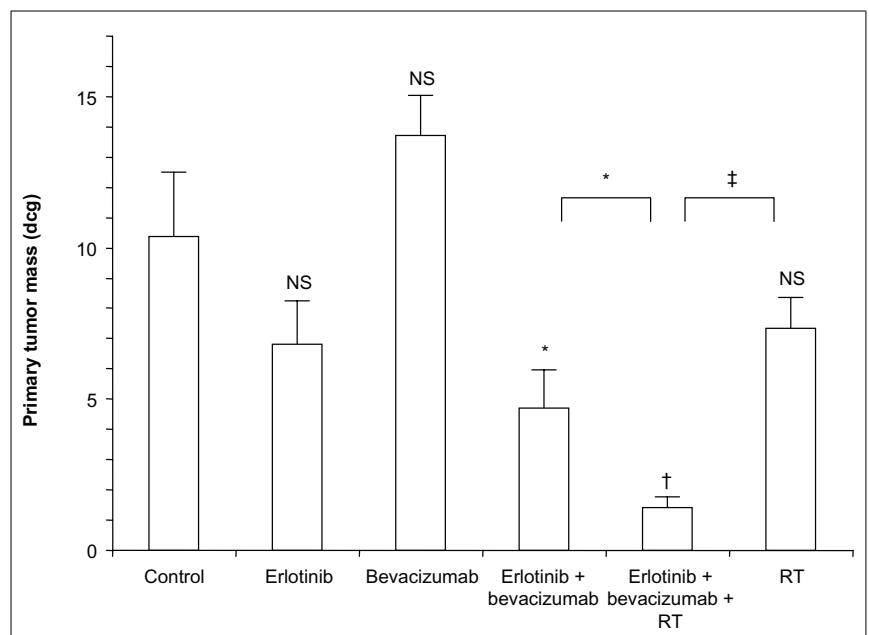

FIGURE 3 | Primary tumor growth after 10 days of treatment with single agents and combinations (10 mice per treatment group). Bars denote SD. Values above the columns concern comparisons with the controls; other values concern comparisons between two following columns. ${ }^{*} P<0.05 ;{ }^{\dagger} P<0.01 ;{ }^{\ddagger} P<0.001$; NS, non-significant $(P>0.05)$; $\mathrm{RT}$, radiotherapy. Reprinted by permission from (Bozec et al., 2008), copyright 2008

benefit beyond that observed with either modality administered as monotherapy.



oral gavage), RT (2-Gy fraction twice per week), or the combination for 3 weeks. Points, mean tumor size $\left(\mathrm{mm}^{3}\right.$; six mice per treatment group). Reprinted with permission from Chinnaiyan et al. (2005, Figure 6).

In addition, the antiangiogenic agent bevacizumab in combination with erlotinib and RT was investigated in a preclinical study of the human vascular endothelial growth factor-secreting HNSCC cell line CAL33, which also has a high expression level of EGFR (Bozec et al., 2008). Cells were injected as orthotopic xenografts into the mouth floors of nude mice. Each agent was administered alone and in combination. With the administration of bevacizumab and erlotinib, tumor growth was decreased significantly compared with controls (Figure 3). When RT was added, tumor growth was almost completely eliminated, and the total number of pathologically positive lymph nodes was significantly reduced compared with controls.

Together, results of these preclinical studies highlight the potential benefit of combining RT with EGFR inhibition in clinical practice, a strategy that is under investigation in multiple clinical trials.

\section{CLINICAL DATA IN HNSCC}

The treatment of patients with head and neck cancer has been continually evolving. Treatment of patients with unresectable tumors has moved from definitive RT to chemoradiotherapy in the last decade. In HNSCC, EGFR overexpression has been demonstrated in $95-100 \%$ of tumors (Salomon et al., 1995). Erlotinib has been evaluated in the treatment of head and neck cancers, demonstrating modest single-agent activity in the setting of metastatic refractory HNSCC [response rate (RR), 4.3\%; stable disease (SD), 
$38.3 \%$ for a median duration of 16.1 weeks; Soulieres et al., 2004]. In the salvage setting, erlotinib has been combined with docetaxel and cisplatin (RR, 67\%; disease control rate, 95\%) with good results (Kim et al., 2007).

Several phase II and phase III trials have evaluated the combination of erlotinib and RT in the definitive treatment of HNSCC (Table 1), although published data are limited. Erlotinib in combination with cisplatin and RT was evaluated in a phase I/II study of patients with stage III and IV HNSCC (Herchenhorn et al., 2010). A standard chemoradiotherapy regimen was used, with RT administered for 5 days, for a total dose of 70.2 Gy over 8 weeks, and cisplatin administered at a dose of $100 \mathrm{mg} / \mathrm{m}^{2}$ every 3 weeks. In the dose-escalation phase, no dose-limiting toxicity was observed for erlotinib at $150 \mathrm{mg} /$ day; this dosage was subsequently employed in the phase II trial. Twenty-three of the 31 patients treated at this dosage had pathologic complete responses (CRs) as assessed by imaging and biopsy. At a median follow-up of 37 months, 3year progression-free survival (PFS) and OS rates were 61 and $72 \%$, respectively. Grade 3 and 4 adverse events included in-field dermatitis $(n=16)$, nausea $(n=15)$, emesis $(n=12)$, dysphagia $(n=11)$, mucositis $(n=9)$, xerostomia $(n=9)$, acneiform rash $(n=8)$, asthenia $(n=7)$, neutropenia $(n=2)$, renal failure $(n=2)$, and diarrhea $(n=1)$. The dose of cisplatin was reduced in seven patients, and treatment was stopped in four patients; RT was interrupted in six patients. An unplanned analysis revealed a trend toward superior OS in patients who developed acneiform rash compared with those who did not have acneiform rash. Because of the high CR rate and despite the high toxicity rates, the authors advocated further evaluation of this regimen in clinical trials.

Recent data have emerged that suggest docetaxel with and without RT may be a promising treatment option for patients with head and neck cancer. Erlotinib has also been combined with docetaxel and RT in a phase I study of patients with previously untreated locally advanced HNSCC (Savvides et al., 2006). Patients received standard once-daily RT (70.2 Gy total, given as $1.8 \mathrm{~Gy} /$ day), weekly docetaxel $\left(15-20 \mathrm{mg} / \mathrm{m}^{2}\right)$ for the duration of RT, and daily erlotinib (50-150 mg/kg) for 2 weeks before, during, and up to 2 years after RT. The combination was feasible, with 15 of 18 patients achieving CRs.

Patients with head and neck cancer who undergo surgery and are found to have high-risk features are offered adjuvant RT or chemoradiotherapy to reduce the risk of local recurrence. Although cisplatin that is administered every 3 weeks with concurrent RT is considered to be the standard treatment for HNSCC (National Comprehensive Cancer Network, 2011a), the toxicity associated with this approach is significant. Many community centers treat patients with weekly cisplatin and concurrent RT because it is better tolerated. The Spanish group Grupo de Investigación Clínica en Oncología Radioterápica recently reported on a multicenter, non-randomized phase I/II study investigating the addition of erlotinib to adjuvant chemoradiotherapy in patients with surgically resected locally advanced HNSCC (Arias de la Vega et al., 2008). Twelve patients received RT at a dose of $63 \mathrm{~Gy}$ (1.8 Gy/day over 7 weeks) with weekly cisplatin $\left(30-40 \mathrm{mg} / \mathrm{m}^{2}\right)$ and once-daily erlotinib (100-150 mg). The combination appeared to be feasible in all dosing groups. Dose-limiting toxicities included grades 3 and 4 mucositis, grade 3 folliculitis, and grade 3 respiratory infection. Median treatment duration was more than 7 weeks, and no dose reductions were required. The maximum tolerated dose (MTD) of erlotinib was $150 \mathrm{mg} /$ day, of cisplatin was $30 \mathrm{mg} / \mathrm{m}^{2}$ weekly, and of RT was $63 \mathrm{~Gy}$. The phase II study evaluating this combination is ongoing.

Meluch et al. (2009) combined concurrent chemotherapy or RT with erlotinib and bevacizumab in a phase II trial of patients with previously untreated locally advanced head and neck cancer. Patients first received two cycles of

Table 1 | Recent trials of erlotinib and radiotherapy in head and neck squamous cell carcinoma.

\begin{tabular}{|c|c|c|c|c|c|c|}
\hline Trial & Year & Trial type & $N$ & Treatment & Efficacy outcome & Safety outcomes ${ }^{a}$ \\
\hline $\begin{array}{l}\text { Herchenhorn } \\
\text { et al. (2010) }\end{array}$ & 2009 & $\begin{array}{l}\text { Phase }|/ I| \\
\text { single arm }\end{array}$ & 31 & $\begin{array}{l}\text { Erlotinib + RT } \\
+ \text { cisplatin }\end{array}$ & Pathologic CR, $74.2 \%$ & $\begin{array}{l}\text { Grade } 3 / 4 \text { toxicities: in-field dermatitis }(52 \%) \text {, } \\
\text { nausea }(48 \%) \text {, vomiting }(39 \%) \text {, dysphagia } \\
(35 \%) \text {, mucositis }(29 \%) \text {, xerostomia }(29 \%)\end{array}$ \\
\hline $\begin{array}{l}\text { Savvides et al. } \\
\text { (2006) }\end{array}$ & 2006 & $\begin{array}{l}\text { Phase I dose- } \\
\text { escalation }\end{array}$ & 23 & $\begin{array}{l}\text { Erlotinib + RT } \\
+ \text { docetaxel }\end{array}$ & $\begin{array}{l}\text { Of } 18 \text { patients, } 15 \text { achieved } \\
\text { CRs }\end{array}$ & DLTs: grade $3 / 4$ mucositis $(n=2)$, death $(n=1)$ \\
\hline $\begin{array}{l}\text { GICOR (Arias } \\
\text { de la Vega } \\
\text { et al., 2008) }\end{array}$ & 2008 & $\begin{array}{l}\text { Phase I dose- } \\
\text { escalation }\end{array}$ & 12 & $\begin{array}{l}\text { Erlotinib + RT } \\
+ \text { cisplatin }\end{array}$ & $\begin{array}{l}\text { MTD: erlotinib, } 150 \text { mg/day; } \\
\text { cisplatin, } 30 \mathrm{mg} / \mathrm{m}^{2} \text { weekly; } \\
\text { RT, } 63 \mathrm{~Gy}\end{array}$ & $\begin{array}{l}\text { Grade } 3 / 4 \text { toxicities: mucositis }(50 \%) \text {; anemia, } \\
\text { welt, syncope, constipation, dysphonia, } \\
\text { dermatitis, asthenia, respiratory infection } \\
\text { (8\% each) }\end{array}$ \\
\hline $\begin{array}{l}\text { Meluch et al. } \\
\text { (2009) }\end{array}$ & 2009 & $\begin{array}{l}\text { Phase II single } \\
\text { arm }\end{array}$ & 48 & $\begin{array}{l}\text { RT + chemotherapy } \\
\text { + erlotinib } \\
\text { + bevacizumab }\end{array}$ & $\begin{array}{l}77 \% \text { ORR; } 18 \text { month PFS: } \\
85 \%\end{array}$ & $\begin{array}{l}\text { Grade } 3 / 4 \text { toxicities during induction: } \\
\text { neutropenia ( } 46 \%) \text {, mucositis }(14 \%) \text {, diarrhea } \\
(14 \%) \text {, hand/foot syndrome ( } 11 \%) \text {, neutropenic } \\
\text { fever }(6 \%) \text {. Local grade } 3 / 4 \text { toxicities during } \\
\text { combined modality therapy: mucositis/ } \\
\text { esophagitis ( } 76 \%)\end{array}$ \\
\hline
\end{tabular}

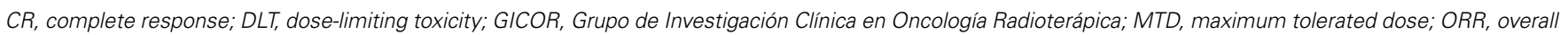
response rate; PFS, progression-free survival; $R T$, radiotherapy.

${ }^{a}$ Most commonly reported moderate-to-severe adverse events. 
paclitaxel/carboplatin/5-fluorouracil (5-FU) plus bevacizumab. Patients $(n=48)$ then received concurrent RT $(68.4$ Gy total at a dose of $1.8 \mathrm{~Gy} /$ day), with paclitaxel, bevacizumab, and erlotinib (150 mg daily $\times 7$ weeks). Among the patients who completed therapy, $56 \%$ responded after induction therapy; $77 \%$ of patients responded after completing therapy. PFS at 18 months was $85 \%$. Toxicities were as expected, but $76 \%$ of patients experienced grade $3(56 \%)$ or $4(20 \%)$ mucositis and/or esophagitis during concurrent therapy.

There is also interest in developing a strategy around erlotinib maintenance therapy following definitive chemoradiotherapy for head and neck cancer. One phase III trial being conducted in Spain in patients with high-risk HNSCC is investigating the effect of erlotinib $150 \mathrm{mg} /$ day on PFS when given as maintenance therapy following concurrent chemoradiotherapy or RT-alone after complete surgical resection (ClinicalTrials.gov, 2010, NCT00412217).

\section{CLINICAL DATA IN NSCLC}

Radiotherapy is a standard treatment for patients with unresectable or locally advanced NSCLC; however, recurrence rates with RT-alone are high, and dual-modality therapy is considered optimal for the treatment of NSCLC (National Comprehensive Cancer Network, 2011b). The BR.21 trial from the National Cancer Institute of Canada Clinical Trials Group showed that erlotinib monotherapy prolonged survival in patients with advanced NSCLC who had progressed after standard chemotherapy (Shepherd et al., 2005), and erlotinib is approved in this setting. Interestingly, EGFR expression does not seem to correlate with response to EGFR inhibitors, although an increased likelihood of response to EGFR inhibitors was associated with never smoking, adenocarcinoma tumor type, female gender, and acquired EGFR adenosine triphosphate-binding site mutations in an expanded access trial of gefitinib (Kim et al., 2005b). A recent analysis of data from the BR.21 trial indicated that EGFR mutations and high copy number are predictive of response to erlotinib (Zhu et al., 2008). In addition, EGFR fluorescence in situ hybridization score was a significant predictive marker of differential survival benefit from erlotinib.
Several studies in NSCLC are now underway to evaluate erlotinib in combination with RT (Table 2). A prospective phase II study found that RT and concurrent erlotinib used in the treatment of patients with unresectable NSCLC shows promising results without an increase in toxicity (Martinez et al., 2008). Patients with unresectable stage I to IIIA NSCLC who were not appropriate candidates for chemotherapy were randomized to three-dimensional thoracic RT at a dose of 66 Gy given in 33 fractions over 6 weeks or the same dose of RT plus concomitant erlotinib at $150 \mathrm{mg} /$ day for 6 months. Adverse events related to RT included esophagitis, radiation dermatitis, and pneumonitis. The addition of erlotinib to RT did not appear to increase RT-associated toxicities. Erlotinibrelated adverse events included mild to moderate skin rash $(61.5 \%)$ and diarrhea $(23 \%)$. The RR was $55.5 \%$ in the RT-alone arm compared with $83.3 \%$ in the erlotinib-plus-RT arm.

The Cancer and Leukemia Group B is conducting a phase II trial, CALGB 30605, of nanoparticle albumin-bound paclitaxel followed by RT and erlotinib in patients with unresectable stage III NSCLC (ClinicalTrials.gov, 2011, NCT00553462). The study is evaluating induction chemotherapy consisting of nab-paclitaxel over $30 \mathrm{~min}$ on days 1,8 , and 15 and carboplatin over $30 \mathrm{~min}$ on day 1. Treatment is repeated every 28 days for two courses. Patients with no disease progression outside the planned radiation field will continue to receive concurrent erlotinib and RT; however, accrual to this study is currently suspended so that potential toxicity concerns can be assessed. Another study in unresectable stage III NSCLC is evaluating concurrent docetaxel, carboplatin, and thoracic RT followed by erlotinib or placebo. This phase III study was started in May 2005 and has an estimated accrual of 380 patients and a primary end point of PFS (ClinicalTrials.gov, 2009a, NCT00153803).

\section{STEREOTACTIC RADIOSURGERY AND ERLOTINIB}

Stereotactic radiosurgery is a technique for delivering a very highdose of RT to a (usually) small target within the body. Unlike conventionally fractionated RT, this technique is typically delivered in fewer than five treatments. Initially, this technique was used only for lesions in the brain, but technologic improvements have

Table 2 | Recent trials of erlotinib and radiotherapy in NSCLC.

\begin{tabular}{|c|c|c|c|c|c|c|c|}
\hline Trial & Year & Trial type & $N$ & Disease type & Treatment & Efficacy outcome & Safety outcomes ${ }^{a}$ \\
\hline $\begin{array}{l}\text { Martinez et al. } \\
\text { (2008) }\end{array}$ & 2008 & $\begin{array}{l}\text { Phase II } \\
\text { randomized }\end{array}$ & 23 & $\begin{array}{l}\text { Unresectable } \\
\text { stage I-IIIA } \\
\text { NSCLC }\end{array}$ & $\begin{array}{l}\text { RT (arm 1) vs. } \\
\text { RT + erlotinib (arm 2) }\end{array}$ & $\begin{array}{l}\text { RR: } \operatorname{arm} 1,55.5 \% \\
\operatorname{arm} 2,83.3 \%\end{array}$ & $\begin{array}{l}\text { Grade } 3 \text { toxicities: arm 1, pneumonitis } \\
(4 \%) \text {; arm } 2 \text {, radiodermatitis }(8 \%)\end{array}$ \\
\hline $\begin{array}{l}\text { Lind et al. } \\
\text { (2009) }\end{array}$ & 2008 & $\begin{array}{l}\text { Phase I } \\
\text { single arm }\end{array}$ & 11 & $\begin{array}{l}\text { NSCLC brain } \\
\text { metastases }\end{array}$ & $\begin{array}{l}\text { WBRT + concurrent } \\
\text { erlotinib }\end{array}$ & $\begin{array}{l}\text { Of } 7 \text { patients with } \\
\text { follow-up imaging, } \\
\text { PRs in } 5 \text { and SD in } 2\end{array}$ & $\begin{array}{l}\text { Grade } 3-5 \text { toxicities: interstitial lung } \\
\text { disease }(18 \%) \text {, acneiform rash }(9 \%) \text {, } \\
\text { fatigue }(9 \%)\end{array}$ \\
\hline $\begin{array}{l}\text { von Pawel } \\
\text { et al. (2008) }\end{array}$ & 2008 & $\begin{array}{l}\text { Case } \\
\text { reports }\end{array}$ & 2 & $\begin{array}{l}\text { NSCLC } \\
\text { recurrent brain } \\
\text { metastases and } \\
\text { parallel thoracic } \\
\text { progression }\end{array}$ & $\begin{array}{l}\text { WBRT + sequential } \\
\text { erlotinib }\end{array}$ & $\begin{array}{l}\text { Survival }>18 \text { and } \\
15 \text { months, } \\
\text { respectively }\end{array}$ & No severe toxicities reported \\
\hline
\end{tabular}

NSCLC, non-small cell lung cancer; PR, partial response; $R R$, response rate; $R T$, radiotherapy; SD, stable disease; WBRT, whole-brain radiotherapy.

${ }^{a}$ Most commonly reported moderate-to-severe adverse events. 
allowed it to be used in the salvage setting of recurrent tumors virtually anywhere in the body. Because the patients considered for treatment with stereotactic radiosurgery often have metastatic disease, a greater understanding of the interaction of systemic agents and biologic agents in combination with this high-dose RT is needed. However, there do not appear to be any ongoing trials evaluating stereotactic radiosurgery in combination with erlotinib. There is one recent report that describes a patient with metastatic NSCLC receiving erlotinib during abdominal hypofractionated RT for metastatic spinal cord compression who experienced fatal acute diarrhea (Silvano et al., 2008). It is not clear whether erlotinib contributed to this complication, but certainly caution is warranted when combining this agent with high-dose RT.

\section{CLINICAL DATA ON BRAIN METASTASES}

Whole-brain RT (WBRT) remains the standard of care for patients with multiple intracranial metastases. There are limited published data demonstrating the safety of delivering WBRT with concurrent erlotinib. A phase I study was performed to evaluate WBRT and concurrent erlotinib in patients with NSCLC and brain metastases (Lind et al., 2009). No treatment-related neurotoxicity was noted in the study. Two patients developed erlotinib-related interstitial lung disease, contributing to death during maintenance therapy. Five of 11 patients developed acneiform rash, all of whom survived for more than 150 days. Notably, the intracranial disease control rate in patients with imaging scans was $100 \%(7 / 7)$ at 3 months, with five patients having a partial response (PR); intracranial progression was confirmed in a single patient with clinical progression on magnetic resonance imaging at 204 days. In addition to these data, a recent report on two patients with previously irradiated, recurrent NSCLC metastases to the brain indicated that these patients survived 18 and 15 months after occurrence of cranial disease when treated with erlotinib, representing an encouraging survival outcome (von Pawel et al., 2008).

The Radiation Therapy Oncology Group is conducting a randomized phase III trial, RTOG-0320, to evaluate WBRT and stereotactic radiosurgery with or without temozolomide or erlotinib in patients with NSCLC and one to three brain metastases (ClinicalTrials.gov, 2009b, NCT00096265). The projected accrual of this study is 380 patients. Arm 1 will receive WBRT followed by stereotactic radiosurgery, arm 2 will receive similar RT as arm 1 plus oral temozolomide (after RT, any chemotherapy regimen is allowed), and arm 3 will receive similar RT as arm 1 plus erlotinib (after RT, any chemotherapy except temozolomide is allowed). Erlotinib will be continued for a maximum of 6 months unless intracranial progression is evident or the patient cannot tolerate treatment.

\section{CLINICAL DATA IN GBM}

Fractionated external beam RT after maximal excision or biopsy is standard therapy for GBM and other high-grade astrocytomas (National Comprehensive Cancer Network, 2011c). The outcome for most of these patients, however, remains poor. An increasing amount of molecular data suggests that erlotinib might be effective in this disease. EGFR is amplified or overexpressed in up to $60 \%$ of GBMs (Salomon et al., 1995). In addition, mutations of the EGFR gene may be present in as many as $50-70 \%$ of EGFRoverexpressing tumors. Most gene mutations associated with GBM affect the extracellular domain and include a large deletion in exons 2-7, resulting in a variant receptor called EGFRvIII, which has ligand-independent kinase activity. The presence of EGFRvIII appears to be associated with a worse prognosis in GBM than when this variant receptor is absent (Heimberger et al., 2005).

The molecular data have prompted investigations into the role of erlotinib in the treatment of patients with GBM (Table 3). A phase II study recently evaluated erlotinib in combination with carboplatin (but not RT) in patients with GBM and no more than two prior relapses (de Groot et al., 2008). Carboplatin was given on day 1 of every 28-day cycle (to a dose of area under the curve $6 \mathrm{mg} / \mathrm{mL} \cdot \mathrm{min})$. The dose of erlotinib was escalated from 150 to $200 \mathrm{mg} /$ day when tolerated. In 43 evaluable patients, one PR was observed, and $47 \%$ of patients achieved SD for a mean of 12 weeks. Median PFS was 9 weeks, and median OS was 30 weeks. Grade 3 or 4 toxicities included fatigue, leukopenia, thrombocytopenia, and rash (requiring dose reduction). The activity of this combination appears to be modest, although future trials may show a benefit with erlotinib-plus-RT in GBM when patients are selected on the basis of molecular or clinical characteristics.

N0177, a phase II trial led by the North Central Cancer Treatment Group, evaluated erlotinib in combination with temozolomide and RT (Brown et al., 2008). A total of 97 patients with GBM underwent resection or biopsy followed by 1 week of erlotinib $150 \mathrm{mg} /$ day, followed by erlotinib with temozolomide $75 \mathrm{mg} / \mathrm{m}^{2} /$ day and RT to a total of $60 \mathrm{~Gy}$. This was then followed by up to six cycles of adjuvant temozolomide $200 \mathrm{mg} / \mathrm{m}^{2} /$ day for 5 days every 28 days. Sixty-one percent of these patients were alive after 1 year, and median survival was 15 months. However, no benefit was observed when these results were compared with historical controls from the RT-plus-temozolomide arm of the European Organisation for Research and Treatment of Cancer 26981 trial. In addition, EGFR expression in this trial did not correlate with improved outcomes. Although the theoretic rationale for incorporating erlotinib into standard RT and temozolomide is compelling, the clinical data supporting this regimen must be considered preliminary.

Another phase II study evaluated erlotinib with RT and temozolomide in 65 patients with newly diagnosed GBM or gliosarcoma (Prados et al., 2009). Patients received $100 \mathrm{mg}$ /day of erlotinib during RT and $150 \mathrm{mg} /$ day after RT. Patients receiving enzymeinducing antiepileptic drugs received $200 \mathrm{mg}$ /day of erlotinib during RT and $300 \mathrm{mg}$ /day after RT. Temozolomide was given during and after RT. The median survival in this study was 19.3 months compared with 14.1 months in the combined historical control studies, with a hazard ratio for survival (treated/control) of 0.64 (95\% confidence interval, 0.45-0.91). These findings suggest that further studies of this combination are warranted.

\section{CLINICAL DATA IN ESOPHAGEAL CANCER}

EGFR protein expression is present in approximately 30-70\% of esophageal carcinomas and has been correlated with poor patient prognosis and inferior response to conventional treatment (Hanawa et al., 2006; Wang et al., 2007). In addition, EGFR amplification is present in approximately $15 \%$ of esophageal carcinomas, but EGFR mutations are rare (Hanawa et al., 2006). In a phase II study of patients with gastroesophageal junction/cardia and distal 
Table 3 | Recent trials of erlotinib and RT in GBM, esophageal cancer, and pancreatic cancer.

\begin{tabular}{|c|c|c|c|c|c|c|c|}
\hline Trial & Year & Trial type & $N$ & Disease type & Treatment & Efficacy outcome & Safety outcomes ${ }^{a}$ \\
\hline $\begin{array}{l}\text { de Groot et al. } \\
\text { (2008) }\end{array}$ & 2008 & $\begin{array}{l}\text { Phase II single } \\
\text { arm }\end{array}$ & 43 & $\begin{array}{l}\text { Recurrent } \\
\text { GBM }\end{array}$ & $\begin{array}{l}\text { Carboplatin } \\
\text { + erlotinib (no } \\
\text { RT) }\end{array}$ & $\begin{array}{l}\text { SD, } 47 \% \text { for average } \\
\text { of } 12 \text { weeks; median } \\
\text { PFS, } 9 \text { weeks }\end{array}$ & $\begin{array}{l}\text { Grade } 3 / 4 \text { toxicities: lymphopenia } \\
(47 \%) \text {, neutropenia }(35 \%) \text {, thrombo- } \\
\text { cytopenia ( } 35 \%) \text {, fatigue ( } 23 \%) \text {. One } \\
\text { treatment-related death }\end{array}$ \\
\hline $\begin{array}{l}\text { Brown et al. } \\
\text { (2008) }\end{array}$ & 2008 & $\begin{array}{l}\text { Phase II } \\
\text { compared with } \\
\text { historical } \\
\text { controls }\end{array}$ & 97 & GBM & $\begin{array}{l}\text { Erlotinib } \\
+ \text { temozolomide } \\
+\mathrm{RT}\end{array}$ & $\begin{array}{l}\text { Median survival, } \\
15 \text { months; no } \\
\text { benefit vs. historical } \\
\text { controls }\end{array}$ & $\begin{array}{l}\text { Grade } \geq 2 \text { toxicities: rash }(42 \%) \text {, diar- } \\
\text { rhea }(10 \%)\end{array}$ \\
\hline $\begin{array}{l}\text { Dobelbower } \\
\text { et al. (2006) }\end{array}$ & 2006 & $\begin{array}{l}\text { Phase I dose- } \\
\text { escalation }\end{array}$ & 11 & $\begin{array}{l}\text { Esophageal } \\
\text { cancer }\end{array}$ & $\begin{array}{l}\text { Concurrent } \\
\text { erlotinib } \\
+5 \text {-FU } \\
+ \text { cisplatin } \\
+ \text { RT }\end{array}$ & $\begin{array}{l}\text { Feasible } \\
\text { combination; } 2 \\
\text { discontinuations not } \\
\text { related to erlotinib }\end{array}$ & $\begin{array}{l}\text { Grade } 3 / 4 \text { toxicities: leukopenia (36\%), } \\
\text { dehydration }(27 \%) \text {, neutropenia (18\%), } \\
\text { esophagitis }(18 \%)\end{array}$ \\
\hline $\begin{array}{l}\text { lannitti et al. } \\
\text { (2005) }\end{array}$ & 2005 & $\begin{array}{l}\text { Phase I dose- } \\
\text { escalation }\end{array}$ & 13 & $\begin{array}{l}\text { Locally } \\
\text { advanced } \\
\text { pancreatic } \\
\text { cancer }\end{array}$ & $\begin{array}{l}\text { Erlotinib } \\
\text { + gemcitabine } \\
\text { + paclitaxel + RT, } \\
\text { followed by } \\
\text { maintenance } \\
\text { erlotinib }\end{array}$ & $\begin{array}{l}\text { Median survival, } \\
14.0 \text { months; } 46 \% \\
\text { PR }\end{array}$ & $\begin{array}{l}\text { Acute grade } 3 \text { toxicities }(n=17) \text { : dehy- } \\
\text { dration }(18 \%) \text {, thrombosis }(18 \%) \text {, diar- } \\
\text { rhea }(12 \%) \text {, hypersensitivity }(12 \%)\end{array}$ \\
\hline $\begin{array}{l}\text { Cardenes et al. } \\
\text { (2009) }\end{array}$ & 2009 & Pilot & 8 & $\begin{array}{l}\text { Potentially } \\
\text { resectable } \\
\text { pancreatic } \\
\text { cancer }\end{array}$ & $\begin{array}{l}\text { Neoadjuvant } \\
\text { gemcitabine } \\
\text { + erlotinib + RT }\end{array}$ & $\begin{array}{l}\text { No CRs; } 2 \\
\text { downstaged prior to } \\
\text { surgery; } 1 \text { year PFS; } \\
\text { and OS rates of } 50 \\
\text { and } 75 \% \text {, } \\
\text { respectively }\end{array}$ & $\begin{array}{l}\text { Preoperative grade } 3 \text { toxicities: liver dys- } \\
\text { function, vomiting, neutropenia (13\% } \\
\text { each) }\end{array}$ \\
\hline
\end{tabular}

5-FU, 5-fluorouracil; CR, complete response; DLT, dose-limiting toxicity; GBM, glioblastoma; OS, overall survival; PFS, progression-free survival; PR, partial response; $R T$, radiotherapy; $S D$, stable disease.

${ }^{a}$ Most commonly reported moderate-to-severe adverse events.

gastric adenocarcinomas, the activity of erlotinib as monotherapy in esophageal cancer was modest (objective RR, 9\%) (Dragovich et al., 2006).

The combination of erlotinib with chemoradiotherapy is currently being evaluated (see Table 3). Dobelbower et al. (2006) investigated RT, 5-FU, cisplatin, and erlotinib in a phase I trial of 11 patients with esophageal cancer. Patients were assigned to receive a dose of 50,100 , or $150 \mathrm{mg} /$ day erlotinib given concurrently with RT ( $50.4 \mathrm{~Gy}$ at $1.8 \mathrm{~Gy} /$ day), cisplatin $\left(75 \mathrm{mg} / \mathrm{m}^{2}\right.$, days 8 and 36$)$, and 5 -FU $\left(1000 \mathrm{mg} / \mathrm{m}^{2}\right.$, days $8-11$ and $\left.36-39\right)$. Erlotinib was well tolerated, with the main toxicities being diarrhea, skin rash (grade 1,54.5\%), nausea, and dehydration. All patients experienced esophagitis, mostly grades 1 and 2, during treatment.

A phase II study by Li et al. (2010) found that a regimen of RT with concurrent paclitaxel, cisplatin, and erlotinib for patients with locally advanced esophageal carcinoma had antitumor activity but was accompanied by significant but manageable toxicity. Twenty-four patients received $60 \mathrm{~Gy}$ of RT in 30 fractions along with paclitaxel $135 \mathrm{mg} / \mathrm{m}^{2}$ on days 1 and 29 and cisplatin $20 \mathrm{mg} / \mathrm{m}^{2}$ on days $1,2,3,29,30$, and 31, with dose adjustments as needed. Erlotinib $150 \mathrm{mg} /$ day was given concurrently on days 1 through 42. Acute grade 3 toxicities included leukopenia, esophagitis, and skin rash; four patients were unable to complete both cycles of chemotherapy. Twenty-two patients responded to therapy, including 11 patients with CRs. At median follow-up of 18.7 months, eight patients had distant recurrence; one of them also had failure at the site of the original lesion. The 2-year locoregional control and OS rates were 87.5 and $70.1 \%$, respectively. These initial results suggest that this regimen has potential to enhance local control and improve survival in patients with esophageal cancer. 


\section{CLINICAL DATA IN PANCREATIC CANCER}

Pancreatic cancer remains a difficult disease to treat, and the role of RT in its treatment is controversial. Recent publications have suggested a survival improvement for some patients receiving chemoradiotherapy compared with observation in the adjuvant setting (Berger et al., 2008; Hsu et al., 2010). The combination of erlotinib with concurrent chemoradiation in locally advanced pancreatic cancer has demonstrated promising tumor RRs in the range of $30-40 \%$, with acceptable toxicity and median survival times in excess of 14 months (Iannitti et al., 2005).

The finding that erlotinib in combination with gemcitabine improves outcome and survival in patients with metastatic pancreatic cancer (Moore et al., 2007) prompted the initiation of studies evaluating the role of RT and concurrent erlotinib in this disease (see Table 3). Iannitti et al. (2005) conducted a phase I trial to determine the MTD of erlotinib (50-100 mg/day) that could be used with concurrent gemcitabine, paclitaxel, and RT for patients with locally advanced pancreatic cancer. Seventeen patients, 13 with locally advanced disease and four with positive margins after resection, received $50.4 \mathrm{~Gy}$ of RT in increments of $1.8 \mathrm{~Gy} /$ day along with gemcitabine $75 \mathrm{mg} / \mathrm{m}^{2}$ and paclitaxel $40 \mathrm{mg} / \mathrm{m}^{2}$ once per week for 6 weeks. Maintenance erlotinib $150 \mathrm{mg} /$ day was well tolerated; however, when the erlotinib dose was increased to $75 \mathrm{mg}$ /day or more during chemoradiation, dose-limiting toxicities included diarrhea, dehydration, myelosuppression, rash, and small-bowel stricture. In patients with locally advanced disease, the median survival was 14.0 months, with $46 \%$ achieving PRs, indicating that the use of erlotinib plus chemoradiation in this setting may warrant further study.

In a small pilot study, the combination of neoadjuvant gemcitabine, erlotinib, and short-course RT (30 Gy) was investigated in eight evaluable patients with potentially resectable pancreatic cancer (Cardenes et al., 2009). Patients received 2 weeks of erlotinib $100 \mathrm{mg} /$ day, gemcitabine $300 \mathrm{mg} / \mathrm{m}^{2} /$ week, and $30 \mathrm{~Gy}$ of RT in $3 \mathrm{~Gy} /$ day fractions. Preoperative grade 3 or 4 toxicities were vomiting, neutropenia, and hepatotoxicity, which occurred in one patient each. All patients were able to undergo surgery. Hematologic toxicities were observed in three patients postoperatively, and one patient had delayed gastric emptying. Prior to surgery, no pathologic CRs were observed, but two patients had downstaged disease and no changes in tumor stage were present in the remaining six patients. At a median follow-up of 15 months, three deaths were attributed to distant and/or local recurrences; five of the eight patients were alive.

Another study sought to determine the MTD of erlotinib when administered concurrently with twice-weekly gemcitabine and RT for locally advanced pancreatic cancer (Duffy et al., 2008). Twenty patients were treated with daily erlotinib in combination with gemcitabine $40 \mathrm{mg} / \mathrm{m}^{2}$ over $30 \mathrm{~min}$ twice-weekly and RT delivered at a dose of $1.8 \mathrm{~Gy} /$ day in 28 fractions over 5.5 weeks for a total of $50.4 \mathrm{~Gy}$. After chemoradiation, patients received maintenance weekly gemcitabine $1000 \mathrm{mg} / \mathrm{m}^{2}$ on days 1 and 8 of a 21-day cycle and daily erlotinib for four cycles. The MTD of erlotinib in combination with twice-weekly gemcitabine-based chemoradiation was determined to be $100 \mathrm{mg} /$ day. The $\mathrm{PR}$ rate was $35 \%$, and $53 \%$ of patients had SD. The median survival for all patients was 18.7 months. Together, these findings indicate that RT in combination with erlotinib and chemotherapy is feasible in this setting for which few effective treatment options exist.

\section{CONSIDERATIONS FOR CLINICAL PRACTICE}

Many questions remain with respect to the use of erlotinib in combination with RT. One such question is whether erlotinib should be administered concurrently with RT. Although stopping erlotinib would avoid some of the potentially overlapping toxicities that could occur with coadministration, erlotinib and RT may act synergistically and provide an additional benefit together compared with using either approach alone. Such a benefit, however, has yet to be confirmed in randomized clinical trials. Most trials have evaluated erlotinib given simultaneously with RT, as well as with maintenance erlotinib after RT. The simultaneous approach appears to be feasible; however, a case-by-case evaluation of each patient is needed because no strong evidence exists for either a sequential or concurrent approach.

Another issue to consider is the duration and dose of RT to use with erlotinib and whether these parameters should be modified compared with using RT-alone. In addition, RT treatment approaches vary among institutions (National Comprehensive Cancer Network, 2011a). Combining erlotinib with RT adds to the complexity of treatment decisions, and each patient case should be considered individually.

Clinical trials investigating the efficacy and safety of erlotinib and RT in patients with cancer have not included EGFR status as part of the eligibility criteria. Moreover, few biomarker analyses have been conducted to evaluate the association between EGFR expression and survival parameters in these studies, in part, because of limited sample size and the lack of correlation established in earlier clinical studies of erlotinib without RT. In the N0177 trial of erlotinib with temozolomide and RT in patients with GBM, molecular analyses did not show an association between EGFR expression and outcome (Brown et al., 2008). Given the complex interaction between EGFR signaling and radiation response, additional biomarker studies are needed to define whether there is a correlation between erlotinib and RT treatment with PFS and OS outcomes.

Another consideration is how erlotinib treatment may affect the tolerance of normal adjacent organs that are exposed to RT. Erlotinib and RT may interact negatively in terms of skin reaction. For example, recent case reports suggest that RT can affect the timing and severity of erlotinib-induced cutaneous adverse events (Mitra and Simcock, 2006; Gerber et al., 2007; Lacouture et al., 2007).

Erlotinib-induced rash may heighten or influence the sensitivity of the skin to irradiation effects. When RT is administered prior to erlotinib, the appearance of rash may be delayed in the area of RT but becomes apparent within a few weeks to months after RT has ended. This phenomenon was demonstrated by a case in which a preirradiated area on the back of a 56-year-old man with adenocarcinoma was spared the development of an erlotinib-induced papulopustular rash for 3 weeks compared with the surrounding area (Mitra and Simcock, 2006). RT (64 Gy in 32 fractions) had been initiated approximately 12 months before erlotinib therapy. Similarly, a 55-year-old woman with metastatic NSCLC developed 
a papulopustular rash on the face, upper extremities, and elsewhere 1 week after initiation of erlotinib $150 \mathrm{mg} /$ day (Gerber et al., 2007); however, a rectangular field irradiated with $32 \mathrm{~Gy}$ (single doses of 2 Gy) 2 months earlier did not develop rash until 4 months after irradiation and 2 months after initiation of erlotinib. In a third report, Lacouture et al. (2007) described the case of an 84-year-old woman with NSCLC who received 2 weeks of RT (30 Gy in 10 fractions) on her chest just before initiation of erlotinib. After 5 days of erlotinib therapy, a mild papulopustular rash appeared on her face, but a severe rash was also observed in the preirradiated area on her chest. Further studies are needed to investigate the mechanisms underlying the transient effects of RT on erlotinib-induced rash. It may be caused by a transient immunosuppression owing to a loss of Langerhans and other immunocompetent cells or a temporary depletion of EGFR-containing stem cells in the basal layer of the irradiated area (Mitra and Simcock, 2006). Although erlotinib might also enhance RT-related adverse events and vice versa, the combination of erlotinib with RT has not seemingly resulted in additional unexpected adverse events on the basis of investigations to date. In clinical trials evaluating erlotinib with RT, hematologic toxicities, mucositis, and gastrointestinal toxicities (e.g., diarrhea, vomiting) are among the most commonly reported moderate-tosevere adverse events. However, since the majority of these trials also included a chemotherapy component, the safety of these

\section{REFERENCES}

Arias de la Vega, F., Herruzo, I., de las Heras, M., de la Torre, A., del Rio, L., Contreras, J., Prieto, I., Garcia Saenz, J., and Calvo, F. A. (2008). Erlotinib and chemoradiation in patients with surgically resected locally advanced squamous head and neck cancer (HNSCC): a GICOR phase I study. J. Clin. Oncol. 26, abstr. 6068.

Baumann, M., Krause, M., Dikomey, E., Dittmann, K., Dörr, W., KastenPisula, U., and Rodemann, H. P. (2007). EGFR-targeted anti-cancer drugs in radiotherapy: preclinical evaluation of mechanisms. Radiother. Oncol. 83, 238-248.

Berger, A. C., Garcia, M. Jr., Hoffman, J. P., Regine, W. F., Abrams, R. A., Safran, H., Konski, A., Benson, A. B. III, MacDonald, J., and Willett, C. G. (2008). Postresection CA 19-9 predicts overall survival in patients with pancreatic cancer treated with adjuvant chemoradiation: a prospective validation by RTOG 9704. J. Clin. Oncol. 26, 5918-5922.

Bonner, J. A., Harari, P. M., Giralt, J., Azarnia, N., Shin, D. M., Cohen, R. B., Jones, C. U., Sur, R., Raben, D., Jassem, J., Ove, R., Kies, M. S., Baselga, J., Youssoufian, H., Amellal, N., Rowinsky, E. K., and Ang, K. K. (2006). Radiotherapy plus cetuximab for squamous cell carcinoma of the head and neck. N. Engl. J. Med. $354,567-578$.
Bonner, J. A., Harari, P. M., Giralt, J., Cohen, R. B., Jones, C. U., Sur, R. K., Raben, D., Baselga, J., Spencer, S. A., Zhu, J., Youssoufian, H., Rowinsky, E. K., and Ang, K. K. (2010). Radiotherapy plus cetuximab for locoregionally advanced head and neck cancer: 5-year survival data from a phase 3 randomised trial, and relation between cetuximabinduced rash and survival. Lancet Oncol. 11, 21-28.

Bozec, A., Sudaka, A., Fischel, J. L., Brunstein, M. C., Etienne-Grimaldi, M. C., and Milano, G. (2008). Combined effects of bevacizumab with erlotinib and irradiation: a preclinical study on a head and neck cancer orthotopic model. Br. J. Cancer 99, 93-99.

Brown, P. D., Krishnan, S., Sarkaria, J., Wu, W., Mischel, P., Yong, W. H., Arusell, R., Jenkins, R. B., Buckner, J. C., and Giannini, C. (2008). A phase II trial (N0177) of erlotinib and temozolomide (TMZ) combined with radiation therapy (RT) in glioblastoma multiforme (GBM). J. Clin. Oncol. 26, abstr. 2016.

Cardenes, H. R., Chiorean, E. G., Perkins, S., DeWitt, J., Schmidt, M., Zyromski, N., and Howard, T. J. (2009). "Long-term follow-up of a pilot study using neoadjuvant gemcitabine, erlotinib and hypofractionated radiation therapy for potentially resectable pancreatic cancer,"

regimens reflects the contribution and interaction of all three modalities.

\section{CONCLUSION}

Trials thus far have evaluated RT and erlotinib in an array of cancer types, including HNSCC, NSCLC, and many others. Phase III trials are underway that will help provide more information about the optimal way to combine these two treatment modalities. No striking benefit has been observed in any study combining erlotinib and RT, but modest improvements have been reported with this approach. Certainly, adverse events for either approach do not seem to be exacerbated, and toxicities have been manageable. Thus, based on the evidence, further investigation into the combination of erlotinib and RT is warranted, and results from current studies are eagerly awaited. Importantly, each patient should be treated on a case-by-case basis with careful consideration of individual patient preferences and disease characteristics.

\section{AUTHOR'S CONTRIBUTIONS}

Vivek K. Mehta has been involved in the drafting and revising of the manuscript and has read and approved the final manuscript.

\section{ACKNOWLEDGMENTS}

Support for third-party writing assistance for this manuscript, furnished by Emma Hit, was provided by Genentech, Inc.

in Abstract 228 in 2009 Gastrointestinal Cancers Symposium Proceedings (San Francisco, CA: American Society of Clinical Oncology), January 15-17.

Chinnaiyan, P., Huang, S., Vallabhaneni, G., Armstrong, E. Varambally, S., Tomlins, S. A., Chinnaiyan, A. M., and Harari, P. M. (2005). Mechanisms of enhanced radiation response following epidermal growth factor receptor signaling inhibition by erlotinib (Tarceva). Cancer Res. 65 3328-3335.

ClinicalTrials.gov. (2009a). Erlotinib or Placebo Following Chemoradiotherapy (Chemo/RT) in Stage III NonSmall Cell Lung Cancer (NSCLC). Available at: http://www.clinical trial.gov/ct2/show/NCT00153803 [accessed September 28, 2011].

ClinicalTrials.gov. (2009b). Radiation Therapy and Stereotactic Radiosurgery With or Without Temozolomide or Erlotinib in Treating Patients with Brain Metastases Secondary to Non-Small Cell Lung Cancer. Available at: http://www.clini caltrial.gov/ct2/show/NCT00096265 [accessed September 28, 2011].

ClinicalTrials.gov. (2010). A Study of Tarceva (Erlotinib) in Patients with Resected Head and Neck Squamous Cell Cancer. Available at: http:// www.clinicaltrial.gov/ct2/show/NCT 00412217 [accessed September 28, 2011].
ClinicalTrials.gov. (2011). Carboplatin and Paclitaxel Albumin-Stabilized Nanoparticle Formulation Followed by Radiation Therapy and Erlotinib in Treating Patients with Stage III Non-Small Cell Lung Cancer that Cannot be Removed by Surgery. Available at: http://www.clinicaltri al.gov/ct2/show/NCT00553462 [accessed September 28, 2011]. de Groot, J. F., Gilbert, M. R., Aldape, K., Hess, K. R., Hanna, T. A., Ictech, S., Groves, M. D., Conrad, C., Colman, H., Puduvalli, V. K., Levin, V., and Yung, W. K. (2008). Phase II study of carboplatin and erlotinib (Tarceva, OSI-774) in patients with recurrent glioblastoma. J. Neurooncol. 90, 89-97.

Dobelbower, M. C., Russo, S. M., Raisch, K. P., Seay, L. L., Clemons, L. K., Suter, S., Posey, J., and Bonner, J. A. (2006). Epidermal growth factor receptor tyrosine kinase inhibitor, erlotinib, and concurrent 5-fluorouracil, cisplatin and radiotherapy for patients with esophageal cancer: a phase I study. Anticancer Drugs 17, 95-102.

Dragovich, T., McCoy, S., FenoglioPreiser, C. M., Wang, J., Benedetti, J. K., Baker, A. F., Hackett, C. B., Urba, S. G., Zaner, K. S., Blanke, C. D., and Abbruzzese, J. L. (2006). Phase II trial of erlotinib in gastroesophageal junction and gastric adenocarcinomas: SWOG 0127. J. Clin. Oncol. 24, 4922-4927. 
Duffy, A., Kortmansky, J., Schwartz, G. K., Capanu, M., Puleio, S., Minsky, B., Saltz, L., Kelsen, D. P., and O'Reilly, E. M. (2008). A phase I study of erlotinib in combination with gemcitabine and radiation in locally advanced, non-operable pancreatic adenocarcinoma. Ann. Oncol. 19, 86-91.

Gerber, P. A., Enderlein, E., Homey, B., Muller, A., Boelke, E., and Budach, W. (2007). Radiationinduced prevention of erlotinibinduced skin rash is transient: a new aspect toward the understanding of epidermal growth factor receptor inhibitor associated cutaneous adverse effects. J. Clin. Oncol. 25, 4697-4698.

Hanawa, M., Suzuki, S., Dobashi, Y., Yamane, T., Kono, K., Enomoto, N., and Ooi, A. (2006). EGFR protein overexpression and gene amplification in squamous cell carcinomas of the esophagus. Int. J. Cancer 118, 1173-1180.

Harari, P. M. (2004). Epidermal growth factor receptor inhibition strategies in oncology. Endocr. Relat. Cancer $11,689-708$.

Heimberger, A. B., Hlatky, R., Suki, D., Yang, D., Weinberg, J., Gilbert, M., Sawaya, R., and Aldape, K. (2005). Prognostic effect of epidermal growth factor receptor and EGFRvIII in glioblastoma multiforme patients. Clin. Cancer Res. 11, 1462-1466.

Herchenhorn, D., Dias, F. L., Viegas, C. M. P., Federico, M. H., Araújo, C. M., Small, I., Bezerra, M., Fontão, K., Knust, R. E., Ferriera, C. G., and Martins, R. G. (2010). Phase I/II study of erlotinib combined with cisplatin and radiotherapy in patients with locally advanced squamous cell carcinoma of the head and neck. Int. J. Radiat. Oncol. Biol. Phys. 78, 696-701.

Hsu, C. C., Herman, J. M., Corsini, M. M., Winter, J. M., Callister, M. D., Haddock, M. G., Cameron, J. L., Pawlik, T. M., Schulick, R. D., Wolfgang, C. L., Laheru, D. A., Farnell, M. B., Swartz, M. J., Gunderson, L. L., and Miller, R. C. (2010). Adjuvant chemoradiation for pancreatic adenocarcinoma: The Johns Hopkins Hospital-Mayo Clinic Collaborative Study. Ann. Surg. Oncol. 17, 981-990.

Iannitti, D., Dipetrillo, T., Akerman, P., Barnett, J. M., Maia-Acuna, C., Cruff, D., Miner, T., Martel, D., Cioff, W., Remis, M., Kennedy, T., and Safran, H. (2005). Erlotinib and chemoradiation followed by maintenance erlotinib for locally advanced pancreatic cancer: a phase I study. Am. J. Clin. Oncol. 28, 570-575.

Kim, E. S., Kies, M. S., Glisson, B. S., Tsao, A., Ginsberg, L. E., Holsinger, F. C., Burke, B. J., Truong, M., Papadimitrakopoulou, V. A., and Lippman, S. M. (2007). Final results of a phase II study of erlotinib, docetaxel and cisplatin in patients with recurrent/metastatic head and neck cancer. J. Clin. Oncol. 25, abstr. 6013.

Kim, J. C., Ali, M. A., Nandi, A., Mukhopadhyay, P., Choy, H., Cao, C., and Saha, D. (2005a). Correlation of HER1/EGFR expression and degree of radiosensitizing effect of the HER1/EGFR-tyrosine kinase inhibitor erlotinib. Indian J. Biochem. Biophys. 42, 358-365.

Kim, K. S., Jeong, J. Y., Kim, Y. C., Na, K. J., Kim, Y. H., Ahn, S. J., Baek, S. M., Park, C. S., Park, C. M., Kim, Y. I., Lim, S. C., and Park, K. O. (2005b). Predictors of the response to gefitinib in refractory non-small cell lung cancer. Clin. Cancer Res. 11, 2244-2251.

Lacouture, M. E., Hwang, C., Marymont, M. H., and Patel, J. (2007). Temporal dependence of the effect of radiation on erlotinib-induced skin rash. J. Clin. Oncol. 25, 2140; discussion 2141.

Li, G., Hu, W., Wang, J., Deng, X., Zhang, P., Zhang, X., Xie, C., and Wu, S. (2010). Phase II study of concurrent chemoradiation in combination with erlotinib for locally advanced esophageal carcinoma. Int. J. Radiat. Oncol. Biol. Phys. 78, 1407-1412.

Lind, J. S., Lagerwaard, F. J., Smit, E. F., and Senan, S. (2009). Phase I study of concurrent whole brain radiotherapy and erlotinib for multiple brain metastases from non-small-cell lung cancer. Int. J. Radiat. Oncol. Biol. Phys. 74, 1391-1396.

Marshall, J. L. (2011). Oncology - Colorectal Cancer: Medical Management. Available at: http://www.clini caloptions.com/inPractice/Oncology /Gastrointestinal_Cancer/ch11_GICRC-Nonsurgical.aspx\# [accessed February 22, 2012].

Martinez, E., Martinez, M., Viñolas, N., Casas, F., de la Torre, A., Valcarcel, F., Minguez, J., Paredes, A., Perez Casas, A., and Dómine, M. (2008). Feasibility and tolerability of the addition of erlotinib to $3 \mathrm{D}$ thoracic radiotherapy (RT) in patients (p) with unresectable NSCLC: a prospective randomized phase II study. J. Clin. Oncol. 26, abstr. 7563.

Meluch, A. A., Spigel, D., Burris, H. A., Lane, C., Peyton, J. D., Shipley, D.,
Rubin, M., Stipanov, M., Greco, F. A., and Hainsworth, J. D. (2009). Combined modality therapy with radiation therapy (RT), chemotherapy, bevacizumab, and erlotinib in the treatment of patients (pts) with locally advanced squamous carcinoma of the head and neck. J. Clin. Oncol. 27, abstr. 6012.

Mendelsohn, J. (2001). The epidermal growth factor receptor as a target for cancer therapy. Endocr. Relat. Cancer 8, 3-9.

Mitra, S. S., and Simcock, R. (2006). Erlotinib induced skin rash spares skin in previous radiotherapy field. J. Clin. Oncol. 24, e28-e29.

Moore, M. J., Goldstein, D., Hamm, J., Figer, A., Hecht, J. R., Gallinger, S., Au, H. J., Murawa, P., Walde, D., Wolff, R. A., Campos, D. Lim, R., Ding, K., Clark, G., Voskoglou-Nomikos, T., Ptasynski, M., Parulekar, W., and National Cancer Institute of Canada Clinical Trials Group. (2007). Erlotinib plus gemcitabine compared with gemcitabine alone in patients with advanced pancreatic cancer: a phase III trial of the National Cancer Institute of Canada Clinical Trials Group. J. Clin. Oncol. 25, 1960-1966.

National Comprehensive Cancer Network. (2011a). NCCN Clinical Practice Guidelines in Oncology: Head and Neck Cancers, Version 2.2011. Available at: http://www.nccn. org/professionals/physician_gls/ PDF/head-and-neck.pdf [accessed September 28, 2011].

National Comprehensive Cancer Network. (2011b). NCCN Clinical Practice Guidelines in Oncology: Non-Small Cell Lung Cancer. Available at: http://www.nccn.org/profess ionals/physician_gls/PDF/nscl.pdf [accessed September 28, 2011].

National Comprehensive Cancer Network. (2011c). NCCN Clinical Practice Guidelines in Oncology: Central Nervous System Cancers. Available at: http://www.nccn.org/prof essionals/physician_gls/PDF/cns.pdf [accessed September 28, 2011].

Nyati, M. K., Morgan, M. A., Feng, F. Y., and Lawrence, T. S. (2006). Integration of EGFR inhibitors with radiochemotherapy. Nat. Rev. Cancer 6, 876-885.

Prados, M. D., Chang, S. M., Butowski, N., DeBoer, R., Parvataneni, R., Carliner, H., Kabuubi, P., Ayers-Ringler, J., Rabbitt, J., Page, M., Fedoroff, A. Sneed, P. K., Berger, M. S., McDermott, M. W., Parsa, A. T., Vandenberg, S., James, C. D., Lamborn, K. R., Stokoe, D., and Haas-Kogan, D.
A. (2009). Phase II study of erlotinib plus temozolomide during and after radiation therapy in patients with newly diagnosed glioblastoma multiforme or gliosarcoma. J. Clin. Oncol. 27, 579-584.

Salomon, D. S., Brandt, R., Ciardiello, F., and Normanno, N. (1995). Epidermal growth factor-related peptides and their receptors in human malignancies. Crit. Rev. Oncol. Hematol. 19, 183-232.

Sarkaria, J. N., Carlson, B. L., Schroeder M. A., Grogan, P., Brown, P. D., Giannini, C., Ballman, K. V., Kitange, G. J., Guha, A., Pandita, A., and James, C. D. (2006). Use of an orthotopic xenograft model for assessing the effect of epidermal growth factor receptor amplification on glioblastoma radiation response. Clin. Cancer Res. 12, 2264-2271.

Savvides, P., Agarwala, S. S., Greskovich, J., Argiris, A., Bokar, J., Cooney, M., Hoppel, C., Stepnick, D. W., Lavertu, P., and Remick, S. (2006). Phase I study of the EGFR tyrosine kinase inhibitor erlotinib in combination with docetaxel and radiation in locally advanced squamous cell cancer of the head and neck (SCCHN). J. Clin. Oncol. 24, abstr. 5545

Shepherd, F. A., Rodrigues Pereira, J., Ciuleanu, T., Tan, E. H., Hirsh, V., Thongprasert, S., Campos, D. Maoleekoonpiroj, S., Smylie, M., Martins, R., van Kooten, M., Dediu, M., Findlay, B., Tu, D., Johnston, D., Bezjak, A., Clark, G., Santabárbara, P., Seymour, L., and National Cancer Institute of Canada Clinical Trials Group. (2005). Erlotinib in previously treated non-small-cell lung cancer. N. Engl. J. Med. 353, 123-132.

Silvano, G., Lazzari, G., Lovecchio, M., and Palazzo, C. (2008). Acute and fatal diarrhoea after erlotinib plus abdominal palliative hypofractionated radiotherapy in a metastatic non-small cell lung cancer patient: a case report. Lung Cancer 61, 270-273.

Soulieres, D., Senzer, N. N., Vokes, E. E., Hidalgo, M., Agarwala, S. S., and Siu, L. L. (2004). Multicenter phase II study of erlotinib, an oral epidermal growth factor receptor tyrosine kinase inhibitor, in patients with recurrent or metastatic squamous cell cancer of the head and neck. $J$. Clin. Oncol. 22, 77-85.

Tortora, G., Gelardi, T., Ciardiello, F., and Bianco, R. (2007). The rationale for the combination of selective EGFR inhibitors with cytotoxic 
drugs and radiotherapy. Int. J. Biol. Markers 22(Suppl. 4), S47-S52.

von Pawel, J., Wagner, H., Duell, T., and Poellinger, B. (2008). Erlotinib in patients with previously irradiated, recurrent brain metastases from non-small cell lung cancer: two case reports. Onkologie 31, 123-126.

Wang, K. L., Wu, T. T., Choi, I. S., Wang, H., Resetkova, E., Correa, A. M., Hofstetter, W. L., Swisher, S. G., Ajani, J. A., Rashid, A., and Albarracin, C. T. (2007). Expression of epidermal growth factor receptor in esophageal and esophagogastric junction adenocarcinomas: association with poor outcome. Cancer 109, 658-667.

Yarden, Y. (2001). The EGFR family and its ligands in human cancer: signalling mechanisms and therapeutic opportunities. Eur. J. Cancer 37(Suppl. 4), S3-S8.

Zhu, C. Q., da Cunha Santos, G., Ding, K., Sakurada, A., Cutz, J. C., Liu, N., Zhang, T., Marrano, P., Whitehead, M., Squire, J. A., Kamel-Reid, S., Seymour, L., Shepherd, F. A., Tsao, M. S., and National Cancer Institute of Canada Clinical Trials Group Study BR.21. (2008). Role of KRAS and EGFR as biomarkers of response to erlotinib in National Cancer Institute of Canada Clinical Trials Group Study BR.21. J. Clin. Oncol. 26, 4268-4275.

Conflict of Interest Statement: The author declares that the research was conducted in the absence of any commercial or financial relationships that could be construed as a potential conflict of interest.

Received: 27 October 2011; accepted: 17 March 2012; published online: 10 April 2012.
Citation: Mehta VK (2012) Radiotherapy and erlotinib combined: review of the preclinical and clinical evidence. Front. Oncol. 2:31. doi: 10.3389/fonc.2012.00031

This article was submitted to Frontiers in Radiation Oncology, a specialty of Frontiers in Oncology.

Copyright (c) 2012 Mehta. This is an open-access article distributed under the terms of the Creative Commons Attribution Non Commercial License, which permits non-commercial use, distribution, and reproduction in other forums, provided the original authors and source are credited. 